УДК 629.113

DOI: https://doi.org/10.26642/ten-2020-2(86)-18-23

Д.П. Рубан, к.т.н., доц.

AT «Черкаський автобус»

Л.В. Крайник, д.т.н., проф.

НУ «Львівська політехніка»

Г.Я. Рубан, викладач

Черкаський державний бізнес-коледж

\title{
Прогнозування довговічності лонжеронів каркасу основи автобуса в проблемних місцях
}

\begin{abstract}
В роботі наведено результати оцінки довговічності основи каркасу кузова в проблемних місиях Результати були отримані за допомогою моделювання в середовищі Solidworks 2018 mа при аналізі пошкоджень каркасів кузовів автобусів громадського транспорту на основі довготривалої експлуатачії за даними експлуатуючих організачій. Встановлено, щзо до таких пошкоджень відносять корозійні та втомні руйнування каркасу основи та інших елементів каркасу кузова. На основі аналізу діяльності експлуатуючих організацій встановлено, щяо автобус стає на відновлювальний ремонт при руйнуванні основи, оскільки подальша експлуатація неможлива. Встановлено, що основною проблемою, що унеможливлюе експлуатацію автобуса є структурна корозія у поєднанні із накопиченням втомних руйнувань під дією знакозмінних ииклічних навантажень. Виявлено причини, щуо впливають на характер пошкоджень та швидкість їх утворення: несвоєчасне поновлення антикорозійного захисту та відсутність обробки скритих порожнин, дороги низької якості та високі швидкості руху по цим дорогам, періодичні перевантаження понад допустимої величини. Почкодження каркасу основи, в більшості випадків, виникають поблизу кріплення елементів підвісок та в місиях перепаду підлоги (особливо в автобусах типу «low-entry» $з$ низькопідлоговими накопичувальними площадками в задній частині автобуса). Великі навантаження на задню площадку автобусів вітчизняного виробництва «Атаман» А092Н6 в години пік, враховуючи те, щзо на задній площадиі місия тільки для пасажирів, що стоять, призводять до утворення магістральних втомних тріщин. В результаті такої експлуатації по дорогам низької якості втомне руйнування відбувається приблизно через 210 тис. км, при терміну експлуатації 2 роки. Обгрунтовано, що для прогнозування утворення втомних тріщин та відповідно запобіганню їх утворенню не достатньо тих результатів які були отримані в умовах нестабільного руху в умовах реальної експлуатації. Представлені результати моделювання, які показують кількість циклів до руйнування та виконано порівняння із реаліями експлуатації, на основі яких пояснено утворення осередків зародження втомних тріщин та розроблено рекомендації щодо запобігання розвитку корозійного розтріскування
\end{abstract}

Ключові слова: автобус; каркас основи; прогнозування довговічності; втомне руйнування.

Актуальність теми. Умови експлуатації автобусів громадського транспорту пов'язані із значною кількістю чинників, що впливають на їх ресурс. Основною і найдорожчою складовою автобуса $\epsilon$ його кузов, що при руйнуванні елементів його каркасу обмежує термін експлуатації автобуса. Поточні та відновлювальні ремонти кузова потребують значних матеріальних витрат та обумовлюють тривалі простої. Кузов автобуса несівної конструкції є також і ідентифікатором при постановці на облік (номер VIN). Тому заміна кузова пов'язана з додатковими витратами коштів та часу при його переобліку. При експлуатації автобусів важливо знати чинники впливу на довговічність каркасу кузова, проблемні місця, що потребують уваги в першу чергу. Важливо уникати перевантажень при перевезенні пасажирів, руху по дорогам низької якості 3 мінімально можливими швидкостями. Однак, враховуючи реалії експлуатації, при гонитві перевізників за прибутком, дотримання нормальних умов експлуатації практично неможливе. Таким чином актуальним буде прогнозування довговічності елементів каркасу кузова в проблемних місцях при жорстких умовах експлуатації.

Аналіз останніх досліджень та публікації, на які спираються автори. Сучасні методології проектування кузовів автобусів [1] та засоби автоматичного проектування [2-4] дозволяють виконувати проектування автобусів на належному рівні. Зміна конструкцій базових моделей (на вимоги Правил СЕК $\mathrm{OOH}$ чи потреби споживачів) може призводити до недотримання умов рівноміцності та зменшення довговічності каркасу кузова. Як показує досвід експлуатації введення площадок низького входу послаблює каркас кузова та призводить до руйнування його елементів [5]. Несвоєчасне оновлення антикорозійного захисту та негативний вплив засобів проти обледеніння доріг суттєво скорочують ресурс кузова автобуса. Автобус при інтенсивній експлуатації в м. Київ потребує відновлювального ремонту (із заміною труб каркасу основи) вже через 5 років [6]. При таких відновлювальних ремонтах вирізаються елементи із характерними корозійними пошкодженнями та тріщинами. Однак, провівши дослідження фізико-механічних властивостей елементів каркасу кузова, які зовні не мають явних пошкоджень (ці елементи при відновлювальних ремонтах не замінюють), встановлено, що ці елементи мають численні втомні тріщини [7] та занижені границі міцності та текучості [8]. В результаті такого 
ремонту автобус не буде відповідати умовам пасивної безпеки [9]. Провівши аналіз витрат на експлуатацію встановлено, що динаміка витрат при збільшенні терміну експлуатації автобуса стрімко зростає [10]. Враховуючи те, що ресурс кузова автобуса після відновлювального ремонту буде зменшений та відповідно витрати будуть збільшені, виникає потреба підвищення довговічності кузова та зведення негативних чинників, що зменшують довговічність до мінімуму. Провівши аналіз літературних даних та аналіз пошкоджень каркасів кузовів автобусів, що знаходяться в реальній екстремальній експлуатації в умовах нестабільного руху встановлено, що цих результатів недостатньо для запобігання утворення та розвитку втомних тріщин. При прогнозуванні довговічності елементів каркасу кузова автобуса в проблемних місцях при жорстких умовах експлуатації, можна оцінити мінімальну кількість циклів до руйнування досліджуваного елемента, що дозволить виявити осередки появи втомних тріщин та корозійного розтріскування. На основі таких досліджень можна розробити рекомендації по підвищенню довговічності каркасу кузова як на стадії проектування (змінюючи матеріал, підсилюючи конструкцію чи покращуючи антикорозійний захист) так і в процесі експлуатації (поновлювати антикорозійний захист, розробляти оптимальні маршрути руху в об'їзд доріг низької якості та без пікового перевантаження автобуса із належними швидкостями руху).

Метою статті є прогнозування довговічності каркасу основи автобуса в проблемних місцях на підставі виявлення корозійного руйнування та керування процесом розтріскування для виявлення появи втомної тріщини та для виявлення осередків втомних тріщин та корозійного розтріскування.

Викладення основного матеріалу. Каркас кузова автобуса під час експлуатації підлягає постійним знакозмінним навантаженням. При проектуванні кузова враховуються навантаження від максимальної маси із коефіцієнтом запасу міцності 1,7. Однак, в результаті експлуатації по дорогам низької якості 3 постійними перевантаженнями (в годину пік кількість пасажирів сягає восьмидесяти, при пасажиромісткості 52 пасажири) та із підвищеними швидкостями по цим дорогам неминуча поява тріщин каркасу кузова. Як показує досвід експлуатації, руйнування елементів каркасу кузова відбувається в основному в одних і тих же місцях. На нових автобусах при термінах експлуатації до двох років спочатку утворюються зародження втомних тріщин без впливу корозії. Потім при проникненні вологи та агресивного середовища (солево-пісчані засоби проти обледеніння доріг) розвиток втомної тріщини вже прискорюється під дією корозії. Подальший розвиток магістральної тріщини вже супроводжується взаємовпливом втомного руйнування та корозії. На автобусах із тривалими термінами експлуатації першочергово розвивається корозія, а вже потім при послабленні труб каркасу можуть утворюватись осередки корозійного розтріскування, що призводить то розвитку магістральної втомної тріщини. На рис. 1 зображені місця елементів каркасу кузова, в яких утворюються втомні тріщини під час перевезення пасажирів з не дотриманням нормальних умов експлуатації.

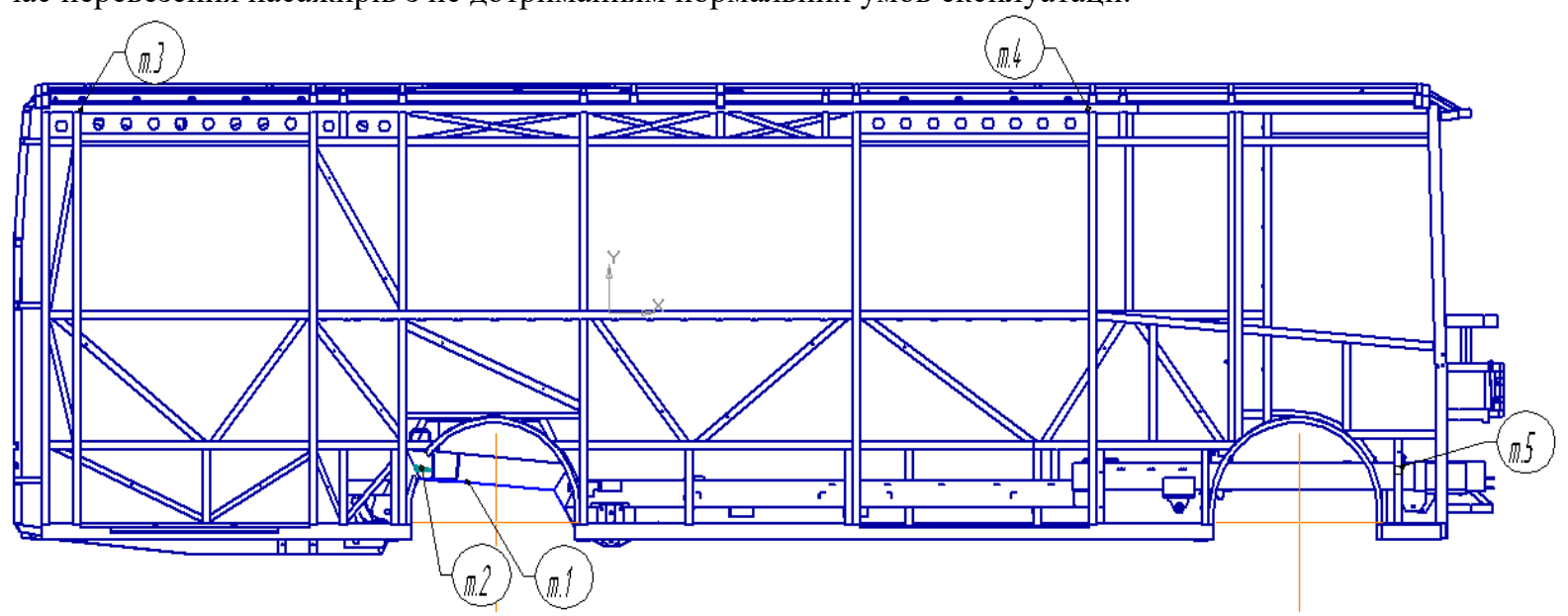

Рис. 1. Місия зародження втомних тріщин каркасу кузова автобуса

На рисунку 1 (т.1) показане місце тріщини каркасу основи поблизу опорної площадки пневморесори. На рисунку 2 зображено фрагмент труби каркасу основи перерізом 140х60х3,6 мм, на якому утворилась втомна тріщина (рис. 1, т.1) у поєднанні із структурною корозією при пробігу близько 700 тис. км та терміном експлуатації до восьми років.

Такі тріщини (рис. 2) систематично виникають при термінах експлуатації 5-9 років, при пробігах 500-900 тис. км навіть при нормальних умовах експлуатації. Такі втомні тріщини виникають у поєднанні із структурною корозією. Як показують неодноразові розтини внутрішньої порожнини труби у місці тріщини розвиток корозії сконцентрований навколо тріщини, на відстані 5-10 мм. Далі поза 5-10міліметровою зоною прояви корозії менш виражені. 


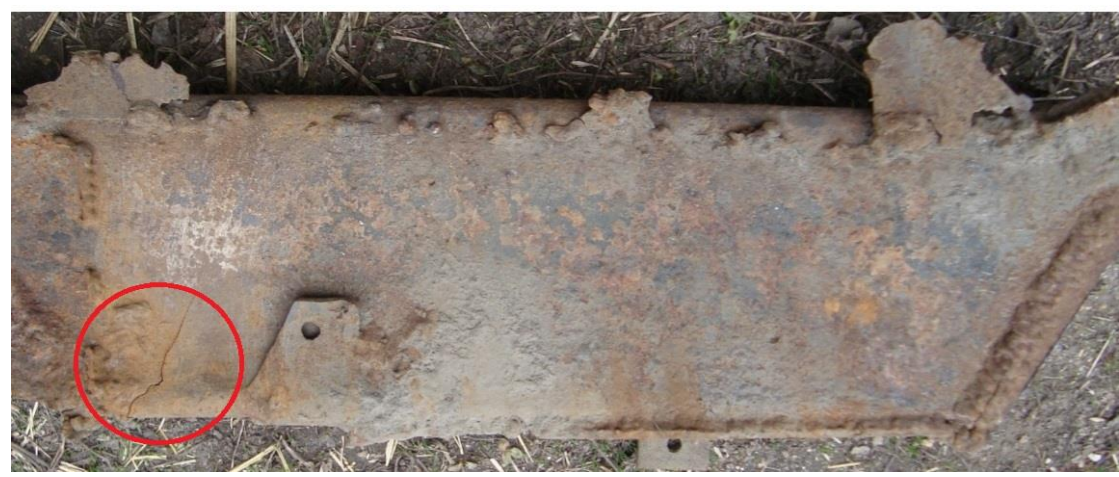

a)

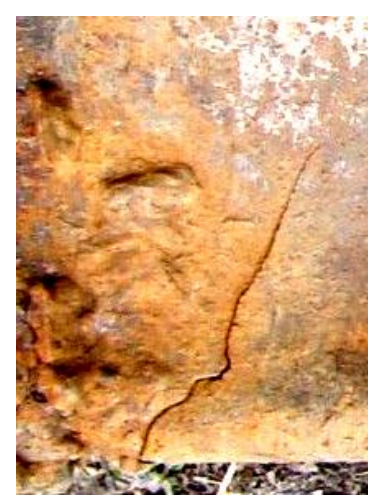

б)

Рис. 2. Втомна тріщина каркасу основи поблизу опорної площзадки пневморесори: а) фрагмент труби каркасу основи з тріщиною; б) місие тріщчини (збільшено)

На рисунку 3 зображено тріщину під дією впливу силових циклічних навантажень, котрі спричинені нерівномірністю завантаження салону та руху по дорогам низької якості (рис. 1, т.2), при пробігу 210 тис. км та близько двох років експлуатації.

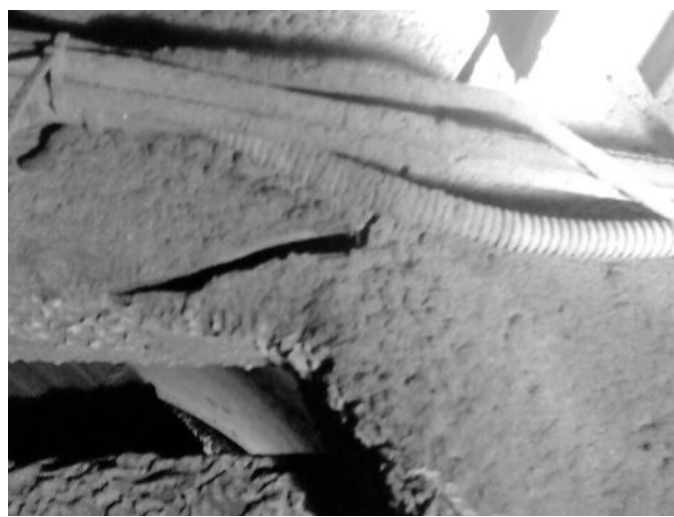

Рис. 3. Втомна тріщина каркасу основи за опорною площадкою пневморесори

Тріщина (рис. 3) утворена тільки під дією знакозмінних циклічних навантажень, оскільки до двох років експлуатації ще діє заводський антикорозійний захист скритих порожнин і корозійні процеси зведені до мінімуму.

Каркас правої боковини послаблений проймами пасажирських дверей, тому при частих перевантаженнях, русі по бруківці неминуча поява тріщин даху. Місця тріщин даху показані на рис. 1 т. 3 та т. 4. На рисунку 4 показаний дефект даху (супутня тріщина) навпроти пройми задніх дверей, яку спровокувала втомна тріщина каркасу правої боковини.

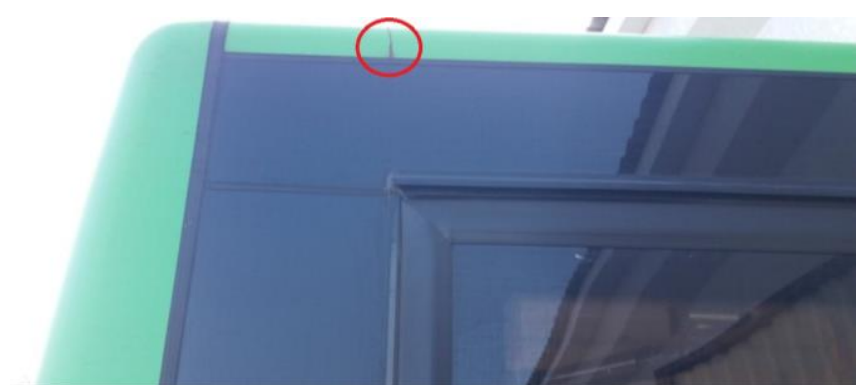

a)

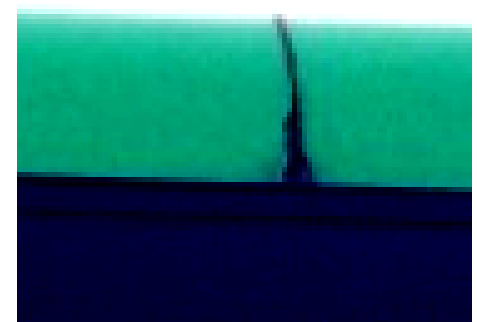

б)

Рис. 4. Втомна тріщина даху при послабленні каркасу правої боковини біля пройми задніх дверей: а) загальний вигляд; б) місие тріщчини (збільшено)

На рисунку 5 показаний дефект даху (супутня тріщина) навпроти пройми передніх дверей, яку спровокувала втомна тріщина каркасу правої боковини. 


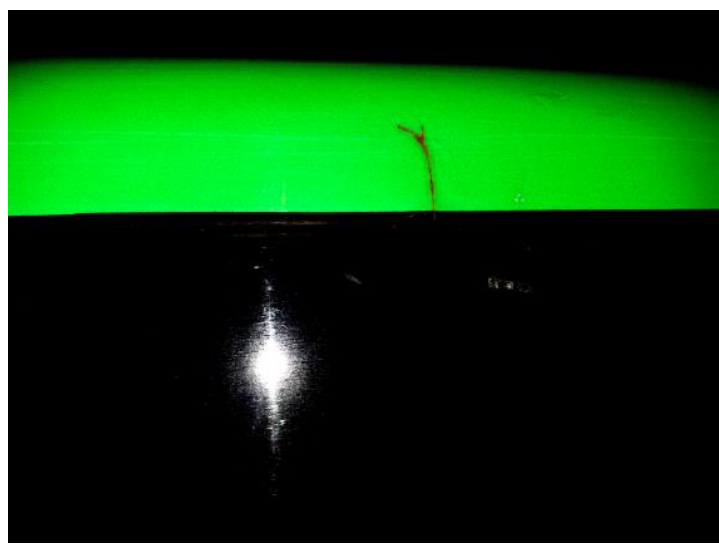

Рис. 5. Втомна тріщина даху при послабленні каркасу правої боковини біля пройми передніх пасажирських дверей

Такі тріщини (рис. 4, 5) почали утворюватися тільки при введенні в конструкцію автобуса задньої підлоги низького входу та використання широких пройм пасажирських дверей. На автобусах «Богдан» базових моделей: А091, А092 з високою підлогою, таких дефектів (рис. 4, 5) не виникало. Тому в такому випадку у відділі головного конструктора слід розробити технічне рішення щодо підсилення каркасу даху.

На рисунку 6 показано місце руйнування з'єднання каркасу основи 3 правою боковиною під дією розвитку магістральної втомної тріщини та корозії, що було вказано при аналізі рис. 1 (т. 5).

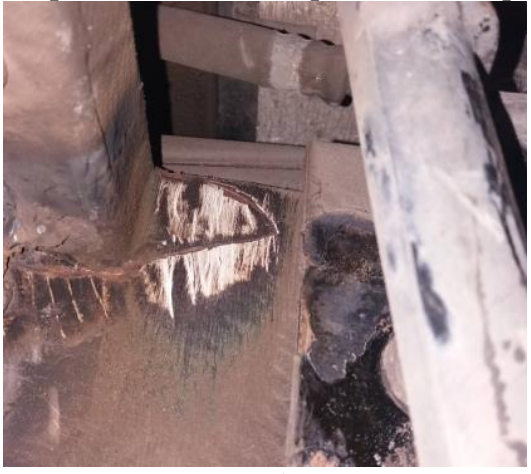

a)

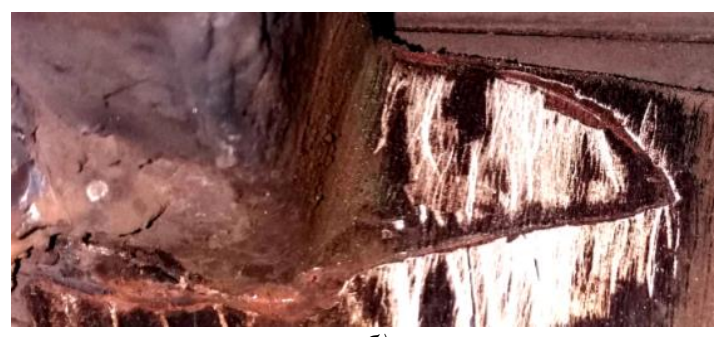

б)

Рис. 6. Місие руйнування з'єднання каркасу основи з правою боковиною під дією магістральної втомної тріщчини та корозї: а) загальний вигляд; б) місце тріщини (збільшено)

Розглянуті дефекти на рисунку 3-6 при експлуатації на дорогах I-III категорій без перевантаження не виникають. Дефект (рис. 2) може виникати при будь-яких умовах експлуатації і чим гірші умови, тим дефект наступить раніше. Таким чином для дослідження обрано елементи каркасу основи в області кріплення пневморесори (рис. 2). Прогнозування довговічності обраних елементів проводилось в середовищі Solidworks 2018. Труби каркасу основи перерізом 140х60х3,6 мм виготовляються зі Сталі S355J2G3 (за ДСТУ 7809:2015 Сталь 20) іноземного виробництва. Параметри цієї сталі, в тому числі й дані для дослідження утворення осередків накопичення втомних тріщин, містяться в бібліотеці Solidworks. Під час моделювання було задано максимально наближений цикл, якому відповідає віднульове навантаження величиною 5000 Н на відстані 500 мм від краю площадки пневморесори (рис. 7).

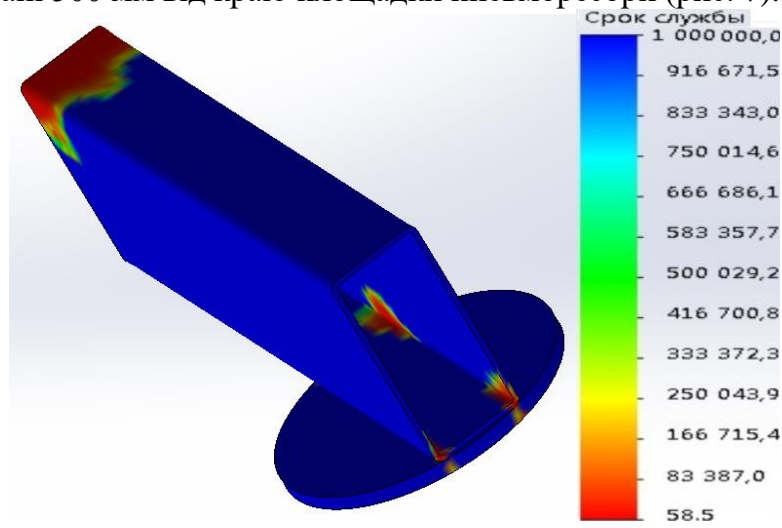

Рис. 7. Елемент каркасу основи в області кріплення пневморесори, щзо взятий для моделювання 
В результаті моделювання експрес-методом встановлено наступне: початок утворення втомної тріщини настав при 59 циклах однієї серії від нульового навантаження, що відповідає близько 200 тис. км реальної експлуатації при середньому навантаженні 5000 Н. На рисунку 7 видно яким чином розподіляються осередки накопичення втомних тріщин. Розглянувши осередки накопичення втомних пошкоджень видно, що із середини труби каркасу основи, навпроти кромки площадки пневморесори спостерігається більша концентрація втомних пошкоджень, ніж із зовнішньої сторони. Під час експлуатації автобуса такі накопичення втомних пошкоджень будуть провокувати розвиток структурної корозії. При подальшій експлуатації буде взаємовплив між утвореними втомними пошкодженнями та корозією. Це пояснює більш інтенсивну корозію поблизу втомної тріщини та те, що корозія у вершині втомної тріщини прискорює процес втомного руйнування.

На рисунку 8 зображено результати моделювання довговічності каркасу основи у місці з'єднання 3 правою боковиною. Каркас основи з'єднується зварюванням з каркасом боковини через трубу перерізом 40x40x2 мм та виготовляється зі Сталі 10. При дослідженнях було задано 1 млн. циклів із зусиллям $1000 \mathrm{H}$ на відстані 500 мм від місця приварювання до труби перерізом 140х60х3,6 мм.

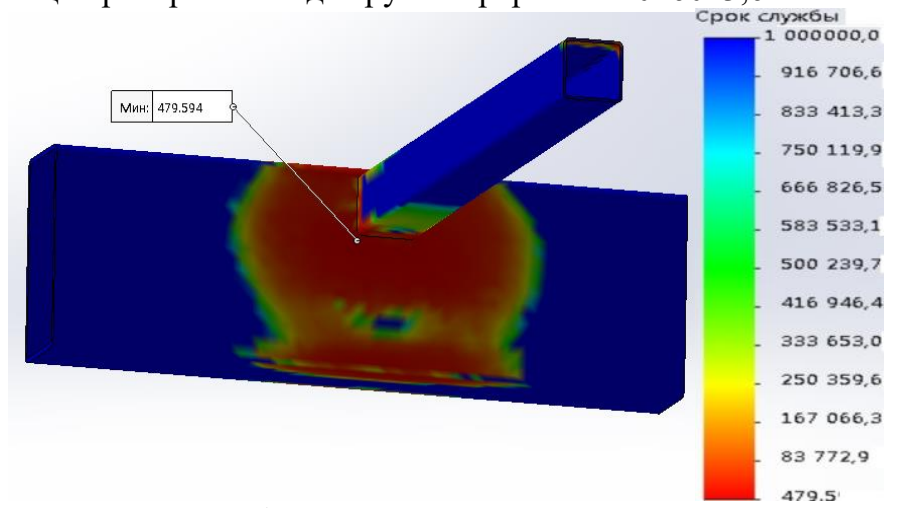

Рис. 8. Елемент каркасу основи (з' єднання труб перерізом 140х60х3,6 мм та 40х40х2 мм), щзо взятий для моделювання

Результати моделювання (рис. 8) підтверджують появу мікротріщин та розвиток магістральних тріщин, які зображені на рис. 6. Утворення тріщини починається при 479 циклах симетричних знакозмінних навантажень, що відповідає пробігу 30 - 40 тис. км реальної експлуатації при середньому навантаженні 1000 Н. Величини циклічних навантажень обрано співрозмірними розрахунковим величинам згідно методології [1] 3 подвійним коефіцієнтом навантажень та жорстких умовах експлуатації при максимально можливому перевантаженні.

В табл. 1 наведено співставлення результатів моделювання 3 пробігами автобусів на реальних маршрутах до утворення тріщин при жорстких умовах експлуатації.

Таблиия 1

Співставлення результатів моделювання з пробігами автобусів на реальних маршрутах до утворення тріщчин при жорстких умовах експлуатації

\begin{tabular}{|c|c|c|c|}
\hline \multirow{2}{*}{$\begin{array}{c}\text { Місце дослідження процесу } \\
\text { пошкоджень каркасу кузова } \\
\text { згідно рис. 1 }\end{array}$} & $\begin{array}{c}\text { Експлуатація автобусів на реальних } \\
\text { маршрутах }\end{array}$ & \multicolumn{2}{|c|}{ Моделювання в програмі Solidworks 2018 } \\
\cline { 2 - 4 } & Середній пробіг до утворення тріщин, км & Навантаження, Н & Кількість циклів до руйнування \\
\hline Точка 5 & $30000-40000$ & 1000 & 479 \\
\hline Точка 1 & $190000-210000$ & 5000 & 59 \\
\hline
\end{tabular}

Якщо розглядати експлуатацію автобусів на реальних маршрутах слід відзначити, що жорсткі умови експлуатації фізично не можуть тривати протягом усього робочого часу. Зокрема в години «пік» це будуть дійсно перевантаження, а у міжпікові періоди автобуси можуть працювати при нормальних умовах, а також не виключені й недовантаження автобусів. Таким чином загальний пробіг автобуса буде формуватися із окремих конкретних режимів експлуатації згідно залежності [11, с. 192]:

$$
S_{\Sigma}=\frac{1}{\frac{\alpha_{1}}{100 S_{1}}+\frac{\alpha_{2}}{100 S_{2}}+\ldots+\frac{\alpha_{n}}{100 S_{n}}},
$$

де $S_{i}$ - можливий пробіг автобуса до появи тріщини в умовах експлуатації при різному завантаженні пасажирами та русі по дорогам різної якості;

$\alpha_{i}$ - час роботи автобуса у відповідних умовах експлуатації у \%.

Такий метод оцінки довговічності може бути використаний при будь-яких співвідношеннях умов експлуатації (різне завантаження пасажирами та рух по дорогам різної якості). Тому на основі існуючих статистичних даних обстеження пасажиропотоків, чи провівши нові обстеження (перевірки) пасажиропотоків можна визначити час роботи автобуса при тих чи інших ступенях завантаження. 
Висновок та перспективи подальших досліджень. На основі прогнозування довговічності лонжеронів каркасу основи з використанням прикладної програми Solidworks 2018 та аналізу утворення тріщин при реальних умовах експлуатації отримано результати, які можуть замінити багато існуючих експрес-методів. А саме: отримані результати моделювання мають високу вірогідність визначення довговічності при циклічних навантаженнях по дорогам низької якості 3 різним завантаженням пасажирами. Результати таких досліджень дозволяють прогнозувати безаварійну роботу каркасів кузовів автобусів, що співставлені з реальними умовами експлуатації з використанням високоточних програмних продуктів, що значно здешевить процес втрат в період міжремонтного циклу. Такі дослідження дозволяють передбачити появу втомних тріщин та вчасно поставити автобус на ремонт, що може суттєво зменшити час його простою. При подальших дослідженнях буде проведено оцінку довговічності каркасу кузова при використанні багатофакторного експерименту, що відповідає руху автобуса по дорогам різної якості при різних циклах навантажень. Для оцінки часу руху автобуса на конкретному маршруті при тих чи інших умовах експлуатації, визначення напружень відповідно до режимів руху буде проведене тензометрування елементів каркасу кузова в проблемних місцях з використанням сучасних портативних засобів тензометрії.

\section{Список використаної літератури:}

1. Горбай О.3. Міцність та пасивна безпека автобусних кузовів : монографія / О.З. Горбай, К.Е. Голенко, Л.В. Крайник. Львів : Видавництво Львівської політехніки, 2013. - 276 с.

2. Dassault Systèmes SolidWorks Corporation. - 2020 [Electronic resource]. - Access mode : https://www.solidworks.com/.

3. Система трехмерного моделирования. - 2020 [Электронный ресурс]. - Режим доступа : https://kompas.ru/.

4. Dassault Systèmes Matlab Corporation. - 2020 [Electronic resource]. - Access mode : https:// www.matlab.com/.

5. Рубан Д.П. Оцінка впливу введення площадок низького входу «low-entry» в структуру несівного кузова на ресурсні характеристики автобуса в експлуатації / Д.П. Рубан, Л.В. Крайник, Г.Я. Рубан // Автомобільний транспорт. - Харків, 2018. - № 43. - С. 31-35

6. Рубан Д.П. Оцінка впливу корозії автобуса на фізичну міцність несівних елементів : матеріали V міжнародної науковопрактичної Інтернет-конференції «Сучасні технології та перспективи розвитку автомобільного транспорту» / Д.П. Рубан, Л.В. Крайник, Г.Я. Рубан. - Вінниця, 2018. - С. 60-64.

7. $\quad$ Рубан Д.П. Оцінка регламентованого терміну експлуатації автобусів з умов відповідності нормативам пасивної безпеки внаслідок корозії та втомної міцності кузова / Д.П. Рубан, Л.В. Крайник // Systemy i Środki transportu samochodowego. Seria : Transport. - Rzeszów : Druk. Pol. Rz., 2017. - № 10. - P. 95-100.

8. Крайник Л.В. Оцінка зміни фізико-механічних властивостей елементів каркасу кузова автобуса в процесі експлуатації / Л.В. Крайник, Д.П. Рубан, Г.Я. Рубан // Вісник Вінницького політехнічного інституту. - Вінниця, 2017. - № 1. - С. 35-40.

9. Сдині технічні приписи щодо офіційного затвердження великогабаритних пасажирських дорожніх транспортних засобів стосовно верхньої частини їхньої конструкції : ДСТУ UN/ECE R 66-00:2002.

10. Крайник Л.В. Витрати у взаємозв'язку з термінами експлуатації міських автобусів / Л.В. Крайник, Д.П. Рубан, Г.Я. Рубан // Вісник НУ «Львівська політехніка». Серія : Динаміка, міцність та проектування машин і приладів. - Львів, 2017. - № 1. C. $127-132$.

11. Основы прочности и долговечности автомобиля / Б.В. Гольд, Е.П. Оболенский, Ю.Г. Стефанович, О.Ф. Трофимов. Москва : Издательство «Машиностроение», 1967. - 212 с.

\section{References:}

1. Gorbaj, O.Z., Golenko, K.E. and Krajnyk, L.V. (2013), Micnist' ta pasyvna bezpeka avtobusnyh kuzoviv : monografija, Vydavnyctvo L'vivs'koi' politehniky, L'viv, 276 p.

2. Dassault Systèmes SolidWorks Corporation (2020), [Online], available at: https://www.solidworks.com/

3. Sistema trekhmernogo modelirovaniya (2020), [Online], available at: https://kompas.ru/

4. Dassault Systèmes Matlab Corporation (2020), [Online], available at: https:// www.matlab.com/.

5. Ruban, D.P., Krajnyk, L.V. and Ruban, G.Ja. (2018), «Ocinka vplyvu vvedennja ploshhadok nyz'kogo vhodu «low-entry» v strukturu nesivnogo kuzova na resursni harakterystyky avtobusa v ekspluatacii'», Avtomobil'nyj transport, Harkiv, No. 43, pp. 31-35.

6. Ruban, D.P., Krajnyk, L.V. and Ruban, G.Ja. (2018), «Ocinka vplyvu korozii' avtobusa na fizychnu micnist' nesivnyh elementiv», materialy V mizhnarodnoi' naukovo-praktychnoi' Internet-konferencii' «Suchasni tehnologii' ta perspektyvy rozvytku avtomobil'nogo transportu», Vinnycja, pp. 60-64.

7. Ruban, D.P. and Krajnyk, L.V. (2017), «Ocinka reglamentovanogo terminu ekspluatacii' avtobusiv z umov vidpovidnosti normatyvam pasyvnoi' bezpeky vnaslidok korozii' ta vtomnoi' micnosti kuzova», Systemy i Środki transportu samochodowego, Seria Transport, Druk. Pol. Rz., Rzeszów, No. 10, pp. 95-100.

8. Krajnyk, L.V., Ruban, D.P. and Ruban, G.Ja. (2017), «Ocinka zminy fizyko-mehanichnyh vlastyvostej elementiv karkasu kuzova avtobusa v procesi ekspluatacii'», Visnyk Vinnyc'kogo politehnichnogo instytutu, Vinnycja, No. 1, pp. 35-40.

9. DSTU UN/ECE R 66-00:2002 Jedyni tehnichni prypysy shhodo oficijnogo zatverdzhennja velykogabarytnyh pasazhyrs'kyh dorozhnih transportnyh zasobiv stosovno verhn'oi' chastyny i'hn'oi' konstrukcii'.

10. Krajnyk, L.V., Ruban, D.P. and Ruban, G.Ja. (2017), «Vytraty u vzajemozv'jazku z terminamy ekspluatacii' mis'kyh avtobusiv», Visnyk NU «L'vivs'ka politehnika», Serija Dynamika, micnist' ta proektuvannja mashyn i pryladiv, L'viv, No. 1, pp. $127-132$.

11. Golg, B.V. (1967), «Osnovi prochnosti i dolgovechnosti avtomobilja», Fundamentals of vehicle strength and durability, Moscow : Izdatelstwo «Maschinostroenie».

Рубан Дмитро Петрович - кандидат технічних наук, доцент, провідний інженер з якості АТ «Черкаський автобус». Наукові інтереси: автомобілебудування.

Крайник Любомир Васильович - доктор технічних наук, професор, професор кафедри автомобілебудування НУ «Львівська політехніка».

Наукові інтереси: автомобілебудування.

Рубан Ганна Яківна - викладач кафедри фундаментальних дисциплін Черкаського державного бізнес-коледжу. Наукові інтереси: фізико-механічні властивості матеріалів під дією знакозмінних навантажень. 